\title{
Evidence for Attenuation of Myo-inositol Uptake, Phosphoinositide Turnover and Inositol Phosphate Production in Aortic Vasculature of Rats During Pregnancy
}

Kirk P. Conrad, * Susan A. Barrera, ${ }^{*}$ Peter A. Friedman, ${ }^{\star}$ and Vicki M. Schmidt

${ }^{*}$ Departments of Physiology and ${ }^{\ddagger}$ Pharmacology and Toxicology, Dartmouth Medical School, Hanover, New Hampshire 03756

\begin{abstract}
We postulated that vascular phosphoinositide metabolism is attenuated during pregnancy, and thereby could contribute to maternal vasodilation and reduced vascular reactivity. The basal rate of incorporation of $\left[{ }^{3} \mathrm{H}\right]$ myo-inositol and $\left[{ }^{3} \mathbf{H}\right]$ glycerol into phosphoinositides of aortae from pregnant rats in vitro was significantly reduced, when compared with vessels from virgin animals. After injection of $\left[{ }^{3} \mathrm{H}\right] \mathrm{myo}$-inositol intravenously into chronically instrumented conscious pregnant and virgin rats, the incorporation of the label by phosphatidylinositol was $66 \pm 4 \%$ less in aortae of gravid versus virgin animals (P $<0.001$ ), despite comparable plasma concentrations of radioactivity. Fold stimulation of total $\left[{ }^{3} \mathrm{H}\right]$ inositol phosphates by arginine vasopressin, norepinephrine, and angiotensin II over a 15min period was not different between aortic segments from virgin and gravid rats, although both absolute basal and stimulated levels were significantly less in vessels from pregnant animals. After $45 \mathrm{~s}$ of incubation with $10^{-7} \mathrm{M}$ arginine vasopressin, however, the fold-stimulation of $\left[{ }^{3} \mathrm{H}\right]$ inositol trisplus tetrakisphosphate was reduced in aortae from gravid rats, when compared with vessels from virgin animals $(P<0.005)$. By HPLC, $>90 \%$ of the radioactivity in the $\left[^{3} \mathrm{H}\right]$ inositol trisplus tetrakisphosphate column fraction after 30 and $60 \mathrm{~s}$ of agonist stimulation was $\left[{ }^{3} \mathrm{H}\right]$ inositol-1,4,5-trisphosphate. We further observed that the rate of uptake of $\left[{ }^{3} \mathrm{H}\right]$ myo-inositol by aortic vasculature obtained from gravid rats was significantly (24\%) less than uptake by vessels from virgin animals. Plasma myo-inositol concentrations were not significantly different, but presumably as a consequence of reduced uptake, aortic segments freshly isolated from pregnant rats contained $22 \pm 6 \%$ less myo-inositol than vessels from virgin controls as measured by gas chromatography-mass spectrometry $(P<0.03)$. We conclude that myo-inositol uptake and content, phosphoinositide turnover, and inositol phosphate production are reduced in aortic vasculature of gravid rats. (J. Clin. Invest. 1991. 87:1700-1709.) Key words: vasodilation • vascular reactivity • norepinephrine $\bullet$ arginine vasopressin $\bullet$ angiotensin II $\bullet$ chronically instrumented conscious rats
\end{abstract}

Portions of this work have appeared in abstract form in 1988. Clin. Res. 36: 480a., and 1990. J. Am. Soc. Nephrol. 1:487.

Address correspondence and reprint requests to Dr. Kirk P. Conrad, Departments of Physiology and Obstetrics/Gynecology, University of New Mexico School of Medicine, BMSB, 2211 Lomas Boulevard NE, Albuquerque, NM 87131.

Received for publication 6 June 1990 and in revised form 28 November 1990

J. Clin. Invest.

(c) The American Society for Clinical Investigation, Inc.

0021-9738/91/05/1700/10 \$2.00

Volume 87, May 1991, 1700-1709

\section{Introduction}

Vasodilation of the maternal circulation is a constant feature of normal human pregnancy. Cardiac output, renal blood flow, and glomerular filtration rate increase by 30 to $60 \%(1-3)$ while blood pressure declines $(4,5)$. Furthermore, pressor response to administration of angiotensin II (6) and vascular reactivity to infusion of norepinephrine (7) become attenuated. Insight into the mechanisms responsible for these phenomena may be particularly critical because attenuation of vascular responses to angiotensin II and norepinephrine as well as systemic and renal vasodilation are lost in women who develop preeclampsia (6-9).

We have found that the chronically instrumented, conscious rat manifests alterations in renal and cardiovascular function during gestation, which are remarkably similar to those observed in normal gravid women (10-13). Thus, the pregnant rat may be a useful animal model in which to investigate mechanism(s) responsible for maternal vasodilation and attenuated vascular reactivity to vasoconstrictor hormones. Since blood vessels of gravid rats (14-20), rabbits (21), cats (21), and guinea pigs (22) demonstrate decreased vascular reactivity in vitro or in situ, it seems likely that alterations within the vasculature itself are important. Vasoconstrictor receptor desensitization during pregnancy does not appear to account for the refactory vascular response, at least to angiotensin II and arginine vasopressin (23-26). (The density and affinity of alpha $_{1}$-adrenergic receptors on vascular smooth muscle have not been evaluated during pregnancy.) Although controversial, vasodilatory prostaglandins may not be involved in the vasodilation and attenuated vascular reactivity of pregnancy either $(11,22,27)$. A possible role for cyclic guanosine-3',5'-monophosphate and endothelium-derived relaxing factor has been recently suggested $(12,28,29)$. Alternatively, we postulated that intracellular processes which mediate vasoconstriction may be altered during gestation such that vasodilation and reduced vascular reactivity occur. As a first step, we examined phosphoinositide turnover, an early event in the signal transducing pathway, which is critical to vascular smooth muscle contraction $(30,31)$. The results support the view that phosphoinositide turnover, inositol phosphate production, and myo-inositol uptake are significantly attenuated in aortic vasculature of gravid rats. Similar changes in resistance vessels may contribute to vasodilation or to reduced vascular reactivity during pregnancy.

\section{Methods}

Long-Evans female rats of $\sim 98 \mathrm{~d}$ of age were obtained from Charles River Breeding Laboratories (North Wilmington, MA). They were mated, and day 0 of gestation was documented by the presence of spermatozoa in the vaginal lavage. (Rat gestation lasts $22 \mathrm{~d}$.) Agematched virgin animals served as controls. Because we used biochemical procedures that involve short term labeling with the radioactive precursor, $\left[{ }^{3} \mathrm{H}\right]$ myo-inositol and $\left[{ }^{3} \mathrm{H}\right]$ glycerol, freshly isolated aortic tis- 
sue was used in order to obtain sufficient mass of vasculature to yield detectable signals. On the day of study, a gravid (gestational day 18-21) and virgin rat were killed, and the aortae removed and placed in me$\operatorname{dium}\left(37^{\circ} \mathrm{C}, \mathrm{pH} 7.4\right)$ preequilibrated with $95 \% \mathrm{O}_{2} / 5 \% \mathrm{CO}_{2}$. After removal of fat and branching vessels, the aortae were gently perfused to remove residual blood. They were then cut into segments with a sharp razor blade. The endothelium was not removed. The isolation procedure lasted no more than $10 \mathrm{~min}$.

Total water-soluble $\left[{ }^{3} \mathrm{H}\right]$ inositol phosphates. Aortic segments of $0.5-1.0 \mathrm{~cm}$ in length were incubated at $37^{\circ} \mathrm{C}$ in $1.5 \mathrm{ml}$ Earle's Balanced Salt Solution (EBSS) ${ }^{1}+25 \mathrm{mM} N$-2-hydroxyethylpiperazine- $N$ '-2-ethanesulfonic acid, pH 7.4, which contained $6 \mu \mathrm{Ci} / \mathrm{ml}\left[{ }^{3} \mathrm{H}\right]$ myo-inositol (15 Ci/mmol; American Radiolabeled Chemicals, Inc., St. Louis, MO). The medium was saturated with $95 \% \mathrm{O}_{2} / 5 \% \mathrm{CO}_{2}$ and fresh atmosphere was introduced into the vials every $30 \mathrm{~min}$. After incubation for $1,2,3$, or $4 \mathrm{~h}$, the tissues were washed with $2.0 \mathrm{ml}$ ice-cold medium $(\times 5)$. Next, the aortic segments were incubated for $10 \mathrm{~min}$ at $37^{\circ} \mathrm{C}$ in EBSS +25 $\mathrm{mM}$ Hepes, $\mathrm{pH} 7.4$, which contained $10 \mathrm{mM} \mathrm{LiCl}$. $\mathrm{LiCl}$ was used to inhibit breakdown of inositol phosphate(s), thus allowing for their accumulation (mainly inositol monophosphate) in order to facilitate detection by scintillation counting. Agonist (norepinephrine, angiotensin II, arginine vasopressin) or vehicle ( $0.9 \%$ saline or medium) was added for a further $15-\mathrm{min}$ incubation. Tissues were homogenized in $1.0 \mathrm{ml}$ $0.6 \mathrm{~N} \mathrm{HClO}_{4}\left(4^{\circ} \mathrm{C}\right)$. The homogenates were centrifuged at $3,200 \mathrm{~g}$ for 10 min and the supernatant neutralized with $\sim 120 \mu l 5.0 \mathrm{~N} \mathrm{KOH}$. After another centrifugation step to pellet the $\mathrm{KClO}_{4}$, the supernatant was added to $9.0 \mathrm{ml} 5 \mathrm{mM}$ disodium tetraborate. The samples were applied to anion exchange columns (32) (Dowex AG1-X8; Bio-Rad, Richmond, CA). Myo-inositol and glycerophosphoinositol were eluted with two to three successive applications of $10-12 \mathrm{ml}$ each of $60 \mathrm{mM}$ sodium formate $/ 5 \mathrm{mM}$ disodium tetraborate. Total water-soluble $\left[{ }^{3} \mathrm{H}\right]$ inositol phosphates (mainly inositol monophosphate) were eluted at once with $12 \mathrm{ml} 1.0 \mathrm{M}$ ammonium formate/0.1 M formic acid. Duplicate 500 -microliter aliquots were counted in $10 \mathrm{ml}$ scintillation fluid (formula 963; New England Nuclear, Boston, MA) for $20 \mathrm{~min}$ each (model LS 3801; Beckman Instruments, Inc., Wakefield, MA). In preliminary experiments $(n=3)$, the $60 \mathrm{mM}$ sodium formate $/ 5 \mathrm{mM}$ disodium tetraborate effectively removed $\left[{ }^{3} \mathrm{H}\right]$ myo-inositol that failed to come through in the sample void. This solution, however, did not elute $\left[{ }^{3} \mathrm{H}\right]$ inositol-4-phosphate $(<0.3 \%),\left[{ }^{3} \mathrm{H}\right]$ inositol-1,4-bisphosphate $(<0.14 \%)$, or $\left[{ }^{3} \mathrm{H}\right]$ inositol-1,4,5-trisphosphate $(<0.14 \%)$. 1.0 M ammonium formate/0.1 $\mathrm{M}$ formic acid eluted $98.7 \%$ of $\left[{ }^{3} \mathrm{H}\right]$ inositol-1,4,5trisphosphate applied to the columns.

Separation of individual water-soluble $\left[{ }^{3} \mathrm{H}\right]$ inositol phosphates. Aortic segments of $0.5-1.0 \mathrm{~cm}$ in length were incubated at $37^{\circ} \mathrm{C}$ in 1.5 $\mathrm{ml}$ EBSS $+20 \mathrm{mM}$ Hepes, $\mathrm{pH} 7.4$, which contained $\left.10 \mu \mathrm{Ci} / \mathrm{ml} \mathrm{[}{ }^{3} \mathrm{H}\right]-$ myo-inositol. The medium was saturated with $95 \% \mathrm{O}_{2} / 5 \% \mathrm{CO}_{2}$ and fresh atmosphere was introduced into the vials every $30 \mathrm{~min}$. After incubation for $3 \mathrm{~h}$, the tissue was washed with $1.5 \mathrm{ml}$ ice-cold medium $(\times 5)$. Aortic segments were then transferred to fresh medium at $37^{\circ} \mathrm{C}$ (without $\mathrm{LiCl}$ ), and vehicle or $10^{-7} \mathrm{M}$ arginine vasopressin was added for the indicated times (up to $2 \mathrm{~min}$ ). Tissues were homogenized in 1.0 $\mathrm{ml} 0.6 \mathrm{~N} \mathrm{HClO}_{4}\left(4^{\circ} \mathrm{C}\right)$ which contained phytic acid hydrolysate $(\sim 26$ $\mu \mathrm{g}$ phosphorus) (33). The homogenates were centrifuged at $3,200 \mathrm{~g}$ for $10 \mathrm{~min}$ and the supernatant was neutralized with $1.25 \mathrm{ml}$ freon/tri- $n$ octylamine (1:1 vol/vol). After vortexing each sample for $1 \mathrm{~min}$, the phases were separated by centrifugation at $2,000 \mathrm{~g}$ for $5 \mathrm{~min}$. The upper phase was then transferred to a graduated tube, and distilled water was added to produce a final volume of $4 \mathrm{ml}$.

Individual water soluble inositol phosphates were separated by Accell QMA Sep-Pak column chromatography (Waters Associates, Milford, MA) (adapted and modified from reference 33). After application of the sample to the Sep-Pak column, the following reagents were pushed through $(10 \mathrm{ml} / \mathrm{min})$ : distilled water $(5 \mathrm{ml} \times 3), 5 \mathrm{mM} \mathrm{Na}_{2} \mathrm{~B}_{4} \mathrm{O}_{7}$ $(5 \mathrm{ml} \times 3), 0.05 \mathrm{M}$ ammonium formate $/ 0.005 \mathrm{M}$ formic acid $(5 \mathrm{ml}$

1. Abbreviations used in this paper: EBSS, Earl's balanced salt solution; InsP, inositol phosphate; MI, myo-inositol. $\times 2), 0.1 \mathrm{M}$ ammonium formate/0.01 $\mathrm{M}$ formic acid $(5 \mathrm{ml} \times 4), 0.4 \mathrm{M}$ ammonium formate $/ 0.04 \mathrm{M}$ formic acid $(3 \mathrm{ml} \times 4)$, and $1.0 \mathrm{M}$ ammonium formate $/ 0.1 \mathrm{M}$ formic acid $(5 \mathrm{ml} \times 4)$. All solutions, which contained ammonium formate, were made by appropriately diluting the stock solution, 1.0 M ammonium formate/0.1 M formic acid, $\mathrm{pH} 4.75$, with distilled water. Duplicate 500-microliter samples from each fraction were counted by liquid scintillation.

Validation studies using $\left[{ }^{3} \mathrm{H}\right]$ standards without $(n=3)$ and with $(n$ $=1$ to 5 ) tissue were performed. The elution profiles were considerably different from those published (33). For $\left[{ }^{3} \mathrm{H}\right]$ myo-inositol, $99.9 \%$ of the standard was found in the void volume and in the initial water washes; for $\left[{ }^{3} \mathrm{H}\right]$ inositol-4-monophosphate, $98.3 \%$ was eluted in the $0.05 \mathrm{M}$ ammonium formate fraction; for $\left[{ }^{3} \mathrm{H}\right]$ inositol-1,4-bisphosphate, $95.6 \%$ was eluted by $0.1 \mathrm{M}$ ammonium formate; $\left[{ }^{3} \mathrm{H}\right]$ inositol-1,3,4trisphosphate, $\left[{ }^{3} \mathrm{H}\right]$ inositol-1,4,5-trisphosphate, and $\left[{ }^{3} \mathrm{H}\right]$ inositol1,3,4,5-tetrakisphosphate were all eluted by $0.4 \mathrm{M}$ ammonium formate, $97.5 \%, 97.5 \%$ and $98.7 \%$, respectively. Comparable results were obtained with tissue except that inexplicably, $12.2 \%$ of the $\left[{ }^{3} \mathrm{H}\right]$ inositol4-monophosphate came out early in the $\mathrm{Na}_{2} \mathrm{~B}_{4} \mathrm{O}_{7}$ wash. All radioactive standards were obtained from New England Nuclear, except for $\left[{ }^{3} \mathrm{H}\right]-$ myo-inositol which was purchased from American Radiolabeled Chemical, Inc.

HPLC was used to resolve the $\left[{ }^{3} \mathrm{H}\right]$ inositol phosphate (InsP) $)_{1,3,4}$ and $\left[{ }^{3} \mathrm{H}\right]$ Ins $\mathrm{P}_{1,4,5}$ isomers as well as $\left[{ }^{3} \mathrm{H}\right] \operatorname{Ins}_{1,3,4,5}$ in a few of the $0.4 \mathrm{M}$ ammonium formate fractions from the Sep-Pak columns (33). A Rainin Dynamax HPLC (Rainin Instrument Co. Inc., Woburn, MA) with dual pumps and a Partisil $10 \mu$ SAX column was used. The injectate volume was $1.5-2.2 \mathrm{ml}$. The mobile phase consisted of a stock solution of $2 \mathrm{M}$ ammonium formate/ $0.1 \mathrm{M}$ formic acid adjusted to $\mathrm{pH}$ 3.7 with orthophosphoric acid. The mobile phase was run at $1.25 \mathrm{ml} /$ min at a final concentration of $0.85 \mathrm{M}$ ammonium formate for the initial $18 \mathrm{~min}$ and then $1.80 \mathrm{M}$ from 20 to $30 \mathrm{~min}$. Collection of $18-\mathrm{s}$ fractions were made and counted by liquid scintillation. $\left[{ }^{3} \mathrm{H}\right]$ Ins $\mathrm{P}_{1,3,4}$, $\left[{ }^{3} \mathrm{H}\right] \mathrm{Ins} \mathrm{P}_{1,4,5}$, and $\left[{ }^{3} \mathrm{H}\right] \operatorname{Ins} \mathrm{P}_{1,3,4,5}$ had retention times of 5.0-6.3, 6.5-7.5, and 20.0-21.8 min, respectively.

Phosphoinositides, in vitro labeling. Aortic segments of $1.0 \mathrm{~cm}$ in length were incubated in $6 \mu \mathrm{Ci} / \mathrm{ml}\left[{ }^{3} \mathrm{H}\right]$ myo-inositol $(0.47 \mu \mathrm{M})$ for 1,2 , 3 , or $4 \mathrm{~h}$ as described above. They were then washed five times with 2.0 $\mathrm{ml}$ ice-cold medium, and homogenized in $2.0 \mathrm{ml}$ chilled $\mathrm{CHCl}_{3}: \mathrm{CH}_{3} \mathrm{OH}$ : concentrated $\mathrm{HCl}(200: 100: 1)$ and $0.4 \mathrm{ml}$ distilled water. After centrifugation at $1325 \mathrm{~g}$ for $5 \mathrm{~min}$ to separate the phases, the lower chloroform layer which contained lipids was transferred to a 5.0-ml conical vial (Wheaton Instruments, Millville, NJ). The protein was extracted again with fresh solvent. The lower phase was then combined with the first and stored under $\mathrm{N}_{2}$ at $-40^{\circ} \mathrm{C}$. The following day, after removal of a residual aqueous layer, the organic phase was dried (Savant Speedvac Concentrator; Savant Instruments, Inc., Farmingdale, NY or N-Evap; Organomation, South Berlin, MA). Unlabeled phospholipid standards were added to the residue: $25 \mu \mathrm{g}$ phosphatidylinositol-4,5-bisphosphate, $15 \mu \mathrm{g}$ lysophosphatidylinositol, $10 \mu \mathrm{g}$ phosphatidylinositol-4-phosphate, and $10 \mu \mathrm{g}$ phosphatidylinositol (Sigma Chemical Co., St. Louis, MO). The sides of the vials were washed with an additional $0.5 \mathrm{ml}$ of the acidified extraction mixture, and after drying, the residue was resuspended in $100 \mu \mathrm{l} \mathrm{CHCl} 3: \mathrm{CH}_{3} \mathrm{OH}: \mathrm{H}_{2} \mathrm{O}-$ 37.5:12.5:1, and sonicated for $5 \mathrm{~min}$ (Branson Co., Shelton, CT). Thin layer plates coated with Silica Gel $\mathrm{H}+1 \%$ potassium oxalate (Analtec Inc., Newark, DE) were activated for $30 \mathrm{~min}$ at $110^{\circ} \mathrm{C}$. Samples were applied in 1.0-cm lanes, and $50 \mu \mathrm{l} \mathrm{CHCl} 3: \mathrm{CH}_{3} \mathrm{OH}: \mathrm{H}_{2} \mathrm{O}$ was again added to each vial, and then applied to the TLC plates. Lipids were separated by a moving phase of $\mathrm{CHCl}_{3}: \mathrm{CH}_{3} \mathrm{OH}: 4 \mathrm{M} \mathrm{NH}_{4} \mathrm{OH}$ 45:35:10 (34). The spots were visualized with iodine vapor, and after sublimation, scraped into $10 \mathrm{ml}$ scintillation fluid (formula 963; New England Nuclear) and each counted for $20 \mathrm{~min}$.

In several experiments, tissues were labeled with $\left[{ }^{3} \mathrm{H}\right]$ myo-inositol in medium which contained concentrations of myo-inositol (Sigma Chemical Co.) within the physiological range. That is, unlabeled myoinositol was added to the incubation medium to achieve a final concentration of $50 \mu \mathrm{M}$. In some experiments Ham's F12:Eagles Minimum Essential Medium (1:1; Hazelton Systems, Inc., Denver, PA) was used 
instead of EBSS. The myo-inositol concentration of this mixture was $55 \mu \mathrm{M}$.

Additional experiments were conducted using $\left[{ }^{3} \mathrm{H}\right]$ glycerol as a precursor (New England Nuclear). Aortic segments of $1.0 \mathrm{~cm}$ length were incubated in EBSS + $20 \mathrm{mM}$ Hepes, saturated with $95 \% \mathrm{O}_{2} / 5 \% \mathrm{CO}_{2}$, pH 7.4, which contained $50 \mu \mathrm{M}$ myo-inositol (MI), $100 \mu \mathrm{M}$ glycerol, and $6 \mu \mathrm{Ci} / \mathrm{ml}\left[{ }^{3} \mathrm{H}\right]$ glycerol. Three aortic segments were used from each animal. One of the segments was incubated for $1.5 \mathrm{~h}$, a second segment for $3.0 \mathrm{~h}$, and a third also for $3.0 \mathrm{~h}$. The third segment, however, was also incubated with $1 \mu \mathrm{M}$ norepinephrine during the last $1.5 \mathrm{~h}$ of incubation. The tissues were then thoroughly washed in ice-cold medium $(\times 5)$. Phospholipids were extracted and separated by TLC, and counted as described above. Because phosphatidylinositol and phosphatidylserine comigrate in the TLC system previously described, they were scraped from the plate, extracted from the gel, applied to another TLC plate, and separated by a moving phase of $\mathrm{CHCl}_{3}: \mathrm{CH}_{3} \mathrm{OH}: \mathrm{CH}_{3-}$ $\mathrm{COOH}: \mathrm{H}_{2} \mathrm{O}$ (81:10:45:1) (35).

Phosphoinositides, in vivo labeling. Midpregnant and age-matched virgin rats were chronically instrumented with a femoral venous catheter using aseptic technique (11). 5-7 d later, the animals were administered $\left[{ }^{3} \mathrm{H}\right]$ myo-inositol intravenously in a total volume of $250 \mu \mathrm{l} 0.9 \%$ saline. Gravid and virgin rats received $43 \mu \mathrm{Ci} / 275 \mathrm{~g}$ and $50 \mu \mathrm{Ci} / 275 \mathrm{~g}$ body weight, respectively. The catheter was then flushed with an additional $1.0 \mathrm{ml}$ of $0.9 \%$ saline. Blood $(\sim 50 \mu \mathrm{l})$ was drawn at $5,15,30,60$, and 120 min after the injection of $\left[{ }^{3} \mathrm{H}\right]$ myo-inositol, and after centrifugation the plasma was counted for radioactivity ( $10 \mu \mathrm{l}$ in duplicate). At $120 \mathrm{~min}$, the rats were administered $40 \mathrm{mg} / \mathrm{kg}$ i.v. pentobarbital. A laparotomy was quickly performed. The animal was killed by rapidly withdrawing 10-20 cc of blood from the abdominal aorta. The aorta was then removed and placed in ice-cold medium. It was next cleaned, perfused, and cut into two $2.0-\mathrm{cm}$ segments. These segments were thoroughly washed in ice-cold medium $(\times 5)$, subjected to organic extraction, and the phospholipids separated by TLC and counted as described above.

Myo-inositol uptake. Aortic segments were preincubated for $1 \mathrm{~h}$ in EBSS + $20 \mathrm{mM}$ Hepes, saturated with $95 \% \mathrm{O}_{2} / 5 \% \mathrm{CO}_{2}, \mathrm{pH} 7.4$, in the presence and absence of $\mathrm{K}^{+}$. To maintain constant osmolality, additional $\mathrm{NaCl}$ was added to the $\mathrm{K}^{+}$-free medium. The tissues were then transferred to fresh medium, again with and without $\mathrm{K}^{+}$, which contained $1 \mu \mathrm{Ci} / \mathrm{ml}\left[{ }^{3} \mathrm{H}\right]$ myo-inositol and $0.25 \mu \mathrm{Ci} / \mathrm{ml}\left[{ }^{14} \mathrm{C}\right]$ mannitol (American Radiolabeled Chemical, Inc.). Unlabeled myo-inositol was added to produce a final concentration of 35,50 , or $70 \mu \mathrm{M}$. After incubations for $2,5,10,20,60$, or $120 \mathrm{~min}$, the tissues were vigorously, but briefly washed in ice-cold medium and then homogenized in $1.0 \mathrm{~m}$ $0.6 \mathrm{~N} \mathrm{HClO}_{4}$. After centrifugation at $3,200 \mathrm{~g}$ for $10 \mathrm{~min}$, the supernatants were neutralized with $\sim 140 \mu \mathrm{l} 5.0 \mathrm{~N} \mathrm{KOH}$, and the $\mathrm{KClO}_{4}$ was removed by an additional centrifugation step. Radioactivity of the supernatant was determined for $\left[{ }^{3} \mathrm{H}\right]$ and $\left[{ }^{14} \mathrm{C}\right]$. Corrections for efficiency and channel crossovers were made. Extracellular $\left[{ }^{3} \mathrm{H}\right]$ myo-inositol was subtracted from total to obtain intracellular $\left[{ }^{3} \mathrm{H}\right]$ myo-inositol. In an additional experiment, $1 \mathrm{mM}$ final concentration of ouabain was used, instead of deleting $\mathrm{K}^{+}$from the medium.

Plasma concentration of myoinositol, enzymatic-fluorometric assay (adapted and modified from references 36 and 37). $500 \mu \mathrm{l}$ of plasma was chilled on ice and treated with $500 \mu \mathrm{l}$ of ice-cold $0.6 \mathrm{~N} \mathrm{HClO}_{4}$ for 15 $\mathrm{min}$. The mixture was vortexed every $5 \mathrm{~min}$ and the precipitated proteins were pelleted by centrifugation. The supernatant was then treated with $5.0 \mathrm{~N} \mathrm{KOH}$ until the $\mathrm{pH}$ was 7.0. After another centrifugation step, the volume was set to $1.0 \mathrm{ml}$ by tare, and $200 \mu \mathrm{l}$ in triplicate was assayed for MI, and an additional $200-\mu \mathrm{l}$ aliquot served as a blank. In order to destroy endogenous glucose, $20 \mu \mathrm{l}$ of $0.1 \mathrm{~N} \mathrm{NaOH}$ was added and the samples were heated for $20 \mathrm{~min}$ at $75^{\circ} \mathrm{C}$. After cooling to room temperature, endogenous NADH was destroyed by addition of $20 \mu \mathrm{l}$ 1.6 N HCL. After a 10 min incubation, $1,600 \mu \mathrm{l}$ of $50 \mathrm{mM} \mathrm{Na}_{2} \mathrm{CO}_{3}, \mathrm{pH}$ 9.5, was added to each sample, followed by $200 \mu$ l of enzyme mixture. The enzyme mixture was freshly prepared and consisted of $0.24 \%$ bovine serum albumin, $0.5 \mathrm{U} / \mathrm{ml}$ myo-inositol dehydrogenase, and $6 \mathrm{mM}$ NAD in $50 \mathrm{mM} \mathrm{Na}_{2} \mathrm{CO}_{3}$ (all from Sigma Chemical Co.). For the blank,
BSA and NAD were added, but not myo-inositol dehydrogenase. Myoinositol standards were prepared in a final volume of $200 \mu \mathrm{l}$ and ranged from 0 to $12 \mathrm{nmol}$. Fluoroescence was read at $1 \mathrm{~h}$ by which time the reaction had proceeded to completion. Excitation and emission wavelengths were 340 and $482 \mathrm{~nm}$, respectively.

Gas chromatography-mass spectrometry (adapted and modified from references 38 and 39). A 1.0-ml sample of chilled plasma was treated with $1.0 \mathrm{ml}$ of ice-cold $10 \% \mathrm{HClO}_{4}$ for $15 \mathrm{~min}$. The mixture was vortexed every $5 \mathrm{~min}$ and the precipitated proteins pelleted by centrifugation. The supernatant was then treated with $5.0 \mathrm{~N} \mathrm{KOH}$ until the $\mathrm{pH}$ was 7.0. After another centrifugation step, the supernatant was transferred to a 5.0-ml Wheaton vial and 12,500 ng of alpha-methyl-D-mannopyranoside was added as an internal standard (Aldrich Chemical Co., Milwaukee, WI). The mixture was dried down in a savant Speedvac concentrator $\left(2 \mathrm{~h}\right.$ at $\left.45^{\circ} \mathrm{C}\right)$. The sides were then scraped with a small metal spatula, and $250 \mu \mathrm{l}$ of trimethylsilating reagent was added (4.25 ml pyridine, $500 \mu \mathrm{l}$ hexamethyldisilazane, and $250 \mu \mathrm{l}$ trimethylchlorosilane; Aldrich Chemical Co.). After vortexing and sonication, the samples were allowed to incubate for $1 \mathrm{~h}$ at room temperature before a final centrifugation step. Standards containing 20,50, and 100 $\mathrm{ng} / \mu \mathrm{l}$ of myo-inositol and of alpha-methyl-D-mannopyranoside were run and yielded a linear relationship. A standard containing $50 \mathrm{ng} / \mu \mathrm{l}$ of myo-inositol and of alpha-methyl-D-mannopyranoside was processed concurrently with each batch of four to six samples. In this way a "relative response factor" of myo-inositol compared with the internal standard could be calculated, and subsequently used to determine the amount of myo-inositol in the sample. A Finnigan MAT (San Jose, CA) $\mathbf{4 0 0 0}$ gas chromatography-mass spectrometry (GC/MS) system was used. The GC was a Finnigan model 9610 (Econocap SE-54 column, 30 meter $\times 0.25 \mathrm{~mm}$ inside diameter from Alltech Associates, Inc., Avondale, PA). Electron-impact ionization was employed. The sensitivity of the assay was $1 \mathrm{ng}$.

Aortic content of MI. 2-cm segments of freshly isolated aorta were thoroughly washed in ice-cold buffer free of myo-inositol. They were then homogenized in $1.0 \mathrm{ml} 0.6 \mathrm{~N} \mathrm{HClO}_{4}$ and the supernatant neutralized with $5 \mathrm{~N} \mathrm{KOH}$. Myo-inositol content was measured by GC/MS as previously described for plasma.

Analytical procedure. Aortic protein was determined by the technique of Lowry et al. (40) using bovine serum albumin (Sigma Chemical Co.) as a standard.

Statistical analysis. Two factor univariate analysis of variance was used. Appropriate post-hoc tests, $t$ tests and nonparametric tests were applied as needed. $P<0.05$ was taken to be significant.

\section{Results}

Total water-soluble $\left[{ }^{3} \mathrm{H}\right]$ inositol phosphates. After various times of incubation with ${ }^{3} \mathrm{HMI}$, the basal accumulation of total $\left[{ }^{3} \mathrm{H}\right]$ inositol phosphates was significantly less in vasculature of late gravid rats, when compared with that of virgin controls (Fig. 1 and Table I). This finding held whether the data were normalized to milligrams wet weight or protein. Hormone-stimulated accumulation of $\left[{ }^{3} \mathrm{H}\right]$ inositol phosphates was also reduced in tissue from gravid animals (Table I). The ratio of hormone-stimulated to basal production of $\left[{ }^{3} \mathrm{H}\right]$ inositol phosphates (fold stimulation) by aortic vasculature was not significantly different between virgin and pregnant rats (Table II). When various dosages of arginine vasopressin were tested $\left(10^{-9}-10^{-6} \mathrm{M}\right)$, the ratio of stimulated to basal accumulation of total $\left[{ }^{3} \mathrm{H}\right]$ inositol phosphates in aortic vasculature was consistently similar between the two groups of animals $(n=6$, virgin and pregnant rats for each dose, data not shown).

Individual water-soluble $\left[{ }^{3} \mathrm{H}\right]$ inositol phosphates. AVP $\left(10^{-7} \mathrm{M}\right)$ failed to stimulate production of $\left[{ }^{3} \mathrm{H}\right]$ inositol trisphosphate plus tetrakisphosphate at $45 \mathrm{~s}$ in aortic segments 

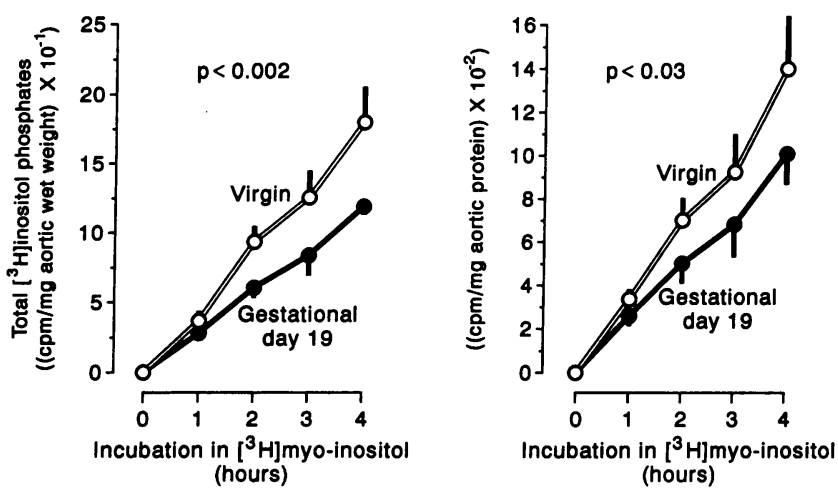

Figure 1. Time course of basal $\left[{ }^{3} \mathrm{H}\right]$ inositol phosphate production in aortic segments obtained from virgin and pregnant rats $(n=7$ animals in each group). The tissues were loaded with $\left[{ }^{3} \mathrm{H}\right]$ myo-inositol for 1 , 2, 3, or $4 \mathrm{~h}$. For further details see Methods. Statistics were performed by two-factor ANOVA; the $P$ values given indicate that basal production of total $\left[{ }^{3} \mathrm{H}\right]$ inositol phosphates was significantly less in tissues from gravid rats when compared to that of virgin controls. Standard error bars are depicted in this figure and in all subsequent figures.

from 3 of 10 virgin and 2 of 10 pregnant rats. Thus, these animals were omitted from the data portrayed in Fig. 2, $A$ and $B$. Note that for the remaining rats, the basal production of $\left[{ }^{3} \mathrm{H}\right]$ inositol phosphates (time 0 ) was consistently less in aortic segments from pregnant animals, as we observed in the study of total water soluble $\left[{ }^{3} \mathrm{H}\right]$ inositol phosphates (Fig. 1 and Table I). After $45 \mathrm{~s}$ of stimulation with AVP, the absolute production of $\left[{ }^{3} \mathrm{H}\right]$ inositol phosphates was also less in vessels from gravid rats (Fig. $2 A, P<0.05$ vs. virgin for $\left[{ }^{3} \mathrm{H}\right]$ inositol monophosphate and $\left[{ }^{3} \mathrm{H}\right]$ inositol bisphosphate). This finding is again consistent with the study of total water-soluble $\left[{ }^{3} \mathrm{H}\right]$ inositol phosphates (Table I). However, the fold stimulation of $\left[{ }^{3} \mathrm{H}\right]$ inositol phosphates by AVP was also reduced for aortae from pregnant animals at the early time point of $45 \mathrm{~s}$ (Fig. $2 B ; P<0.005$ vs. virgin for $\left[{ }^{3} \mathrm{H}\right]$ inositol monophosphate and for $\left[{ }^{3} \mathrm{H}\right]$ inositol trisphosphate plus tetrakisphosphate).

Fig. $3 A$ portrays the separation of the standards $\left[{ }^{3} \mathrm{H}\right]-$ Ins $P_{1,3,4}$ and $\left[{ }^{3} \mathrm{H}\right]$ Ins $P_{1,4,5}$ isomers as well as $\left[{ }^{3} \mathrm{H}\right] \operatorname{Ins} P_{1,3,4,5}$ by HPLC. The 0.4-M ammonium formate fractions obtained from the Sep-Pak columns were applied to the HPLC. Figure 3 $B$ depicts representative HPLC profiles of $\left[{ }^{3} \mathrm{H}\right]$ inositol phosphates synthesized by an aortic segment obtained from a virgin and pregnant rat. The vessels were stimulated with $10^{-7} \mathrm{M}$ AVP for $30 \mathrm{~s}$. Table III summarizes all of the data obtained by HPLC. At 30 and $60 \mathrm{~s}$ after addition of $10^{-7} \mathrm{M}$ arginine vaso- pressin, $\left[{ }^{3} \mathrm{H}\right]$ Ins $\mathrm{P}_{1,4,5}$ constituted $>90 \%$ of the total radioactivity in the $0.4 \mathrm{M}$ ammonium formate fraction obtained from the Sep-Pak columns for tissues from both virgin and pregnant rats. Moreover, the absolute amount of $\left[{ }^{3} \mathrm{H}\right] \mathrm{Ins} \mathrm{P}_{1,4,5}$ produced by aortic segments from pregnant rats was consistently less than that synthesized by tissues from virgin animals, although in these experiments we did not measure basal levels.

Phosphoinositides, in vitro labeling. With a medium myoinositol concentration of $0.47 \mu \mathrm{M}$, incorporation of $\left[{ }^{3} \mathrm{H}\right]$ myoinositol into phosphoinositides of aortae obtained from rats at day 19 of gestation was significantly less than observed in tissues from virgin controls (Fig. 4, $A-D$ ). This finding was obtained whether results were normalized to milligrams wet weight or protein. The magnitude of the reduction in accumulation of total $\left[{ }^{3} \mathrm{H}\right]$ inositol phosphates from aortae of gravid rats discussed above (Fig. 1 and Table I) was comparable to the relative decline in $\left[{ }^{3} \mathrm{H}\right]$ myo-inositol incorporation into aortic phosphoinositides. Specifically, basal $\left[{ }^{3} \mathrm{H}\right]$ inositol phosphate production in vasculature of gravid rats was $73.4 \pm 6.4 \%$ of that produced by aortae from virgin rats, and incorporation of $\left[{ }^{3} \mathrm{H}\right]$ myo-inositol into vascular phosphoinositides of gravid animals was similarly reduced after $3 \mathrm{~h}$ of incubation with the label (phosphatidylinositol-4,5-bisphosphate, $62.8 \pm 5.4 \%$; phosphatidylinositol-4-phosphate, $57.7 \pm 8.3 \%$; phosphatidylinositol, $70.3 \pm 8.5 \%$ ).

When myo-inositol concentration in the medium was adjusted to $50-55 \mu \mathrm{M}$ by adding unlabeled material, tissues from late pregnant animals still incorporated less $\left[{ }^{3} \mathrm{H}\right]$ myo-inositol than those of virgins (Table IV). Finally, the relatively deficient uptake of $\left[{ }^{3} \mathrm{H}\right]$ myo-inositol into phosphoinositides of aortae from gravid rats was observed whether the incubation medium consisted of EBSS or Ham's F12: Eagles Minimum Essential Medium, 1:1 (Table IV).

Fig. 5, $A$ and $B$ depict incorporation of $\left[{ }^{3} \mathrm{H}\right]$ glycerol into phosphatidylinositol and phosphatidylserine. In general, phosphatidylinositol incorporated considerably more label than phosphatidylserine. Norepinephrine further stimulated uptake into phosphatidylinositol, but not into phosphatidylserine. Overall, aortic segments from gravid rats incorporated $19 \pm 5 \%$ less $\left[{ }^{3} \mathrm{H}\right]$ glycerol into phosphatidylinositol than vessels from virgin animals. On the other hand, uptake of the label into phosphatidylserine was comparable in vasculature from gravid and virgin rats.

Phosphoinositides, in vivo labeling. Dosages of $\left[{ }^{3} \mathrm{H}\right] \mathrm{myo}-$ inositol were administered intravenously, such that plasma radioactivity was not significantly different in pregnant and virgin rats (Fig. $6 \mathrm{~A}$ ). (Because endogenous plasma myo-inositol concentration was not significantly different between gravid

Table I. Total ${ }^{3}$ H]Inositol Phosphate Production in Aortic Segments Obtained from Virgin and Pregnant Rats*

\begin{tabular}{|c|c|c|c|c|c|c|}
\hline & Basal & Norepinephrine & Basal & $\begin{array}{c}\text { Arginine } \\
\text { vasopressin }\end{array}$ & Basal & Angiotensin II \\
\hline & & $P<0.01$ & & $P<0.01$ & & $P=N S$ \\
\hline Virgin & $1983 \pm 335$ & $7877 \pm 760$ & $2182 \pm 407$ & $8402 \pm 1308$ & $1735 \pm 319$ & $2799 \pm 554$ \\
\hline Pregnant & $1513 \pm 81$ & $5253 \pm 482$ & $1031 \pm 112$ & $4654 \pm 368$ & $1247 \pm 67$ & $1717 \pm 159$ \\
\hline
\end{tabular}

* Mean \pm SEM. Data are expressed as cpm/mg aortic protein. Six pregnant and six virgin rats were used. After two-factor ANOVA, Tukey tests were employed. When basal levels were combined, a significant difference was obtained by the Mann-Whitney U Test (pregnant: $1,264 \pm 156$ $\mathrm{cpm} / \mathrm{mg}$ aortic protein; virgin: $1,966 \pm 815 \mathrm{cpm} / \mathrm{mg}$ aortic protein $[P<0.04]$ ). 
Table II. Ratio of Vasoconstrictor to Basal Production of Total [ ${ }^{3}$ H]Inositol Phosphates*

\begin{tabular}{lccc}
\hline & \multicolumn{3}{c}{ Fold stimulation by vasoconstrictors } \\
\cline { 2 - 4 } & Norepinephrine & Arginine vasopressin & Angiotensin II \\
\hline Virgin $^{\ddagger}$ & $3.63 \pm 0.27$ & $5.23 \pm 0.64$ & $1.50 \pm 0.11$ \\
Pregnant & $3.33 \pm 0.28$ & $4.70 \pm 0.33$ & $1.45 \pm 0.08$ \\
Virgin" & $3.66 \pm 0.34$ & $4.04 \pm 0.38$ & $1.65 \pm 0.13$ \\
Pregnant & $3.48 \pm 0.31$ & $4.61 \pm 0.20$ & $1.39 \pm 0.13$ \\
\hline
\end{tabular}

* Mean \pm SEM. The data from which these ratios were generated are displayed in Table I. No significant differences were observed between virgin and pregnant rats in the fold stimulation exerted by vasoconstrictors. ${ }^{*}$ The original data were expressed as $\mathrm{cpm} / \mathrm{mg}$ aortic wet weight. "The original data were expressed as $\mathrm{cpm} / \mathrm{mg}$ aortic protein (see Table I).

and virgin rats, either (see below), the plasma specific activity was also comparable.) Uptake of $\left[{ }^{3} \mathrm{H}\right]$ myo-inositol was only detectable in lysophosphatidylinositol and phosphatidylinositol, the two most abundant phosphoinositides (Fig. 6 B). Compared with aortic segments from virgin rats, those from gravid animals incorporated $82 \pm 11 \%$ and $66 \pm 4 \%$ less label into lysophosphatidylinositol and phosphatidylinositol, respectively.

Myo-inositol uptake. The rate of uptake of $\left[{ }^{3} \mathrm{H}\right] \mathrm{myo}$ inositol by aortic vasculature from pregnant rats was $24 \%$ less than $\left[{ }^{3} \mathrm{H}\right]$ myo-inositol uptake by vessels from virgin animals, when medium myo-inositol was $50 \mu \mathrm{M}$ (Fig. $7 A$ ). Uptake of $\left[{ }^{3} \mathrm{H}\right]$ myo-inositol was completely inhibited in vessels from both virgin and pregnant rats by removing $\mathrm{K}^{+}$from the medium (Fig. $7 \mathrm{~B}$ ) or by adding $1 \mathrm{mM}$ ouabain (data not shown). Moreover, differences in uptake at $2 \mathrm{~h}$ were virtually abolished by incubating vessels from pregnant and virgin rats ( $n=5$ each) in 70 and $35 \mu \mathrm{M}$ myo-inositol, respectively (data not shown).

Plasma concentration of myo-inositol. $1 \mathrm{ml}$ of plasma was obtained from three virgin and three late pregnant rats. Using $\left[{ }^{3} \mathrm{H}\right]$ myo-inositol as a tracer, recoveries from the deproteinization procedure were comparable between plasma samples from pregnant and virgin animals and they averaged $62.6 \pm 2.7 \%$. By enzymatic-fluorometric analysis, plasma myo-inositol concentrations were $162 \pm 10$ and $173 \pm 9 \mu \mathrm{M}$ in virgin and pregnant rats, respectively ( $n=10$ each). By GC/MS, values of $87 \pm 8$ and $96 \pm 6 \mu \mathrm{M}$ were observed ( $n=19$ each). Plasma concentrations of myo-inositol were not significantly different between virgin and gravid rats by either method of measurement.

Aortic content of myo-inositol. Using GC/MS, the myo-inositol content of aortic segments from virgin $(n=9)$ and gravid $(n=8)$ rats was $6.6 \pm 0.5$ and $4.9 \pm 0.5 \mathrm{nmol} / \mathrm{mg}$ protein, respectively $(P<0.03)$. Compared with vessels from virgin animals, myo-inositol content was reduced by $22 \pm 6 \%$ in vessels from gravid rats.

\section{Discussion}

Vasodilation of the maternal circulation and attenuation of systemic pressor responsiveness are persistent features of normal human pregnancy. Chronically instrumented, conscious rats also manifest these physiological alterations during pregnancy (10-13). Therefore, the gravid rat may be a useful animal model in which to investigate mechanisms responsible for
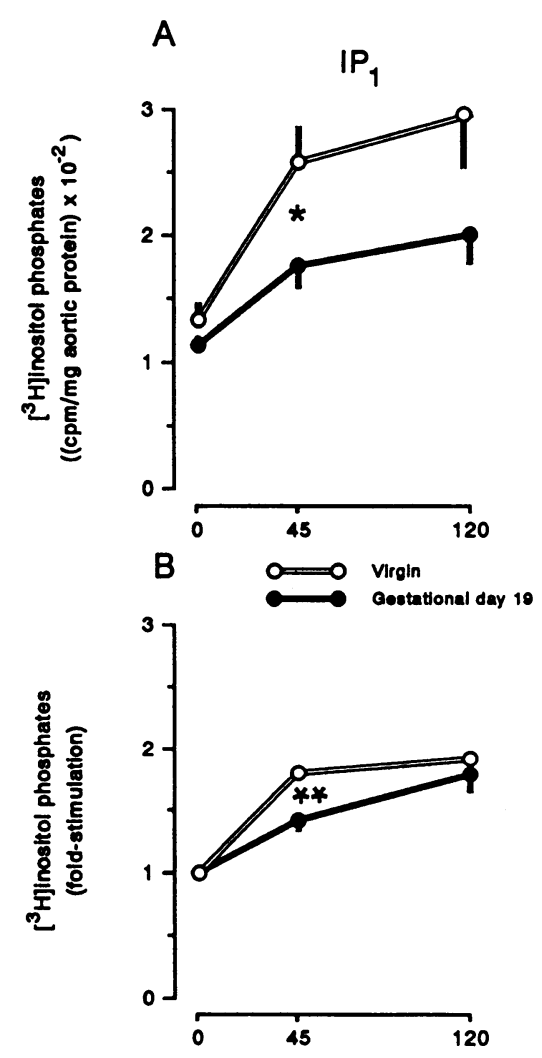
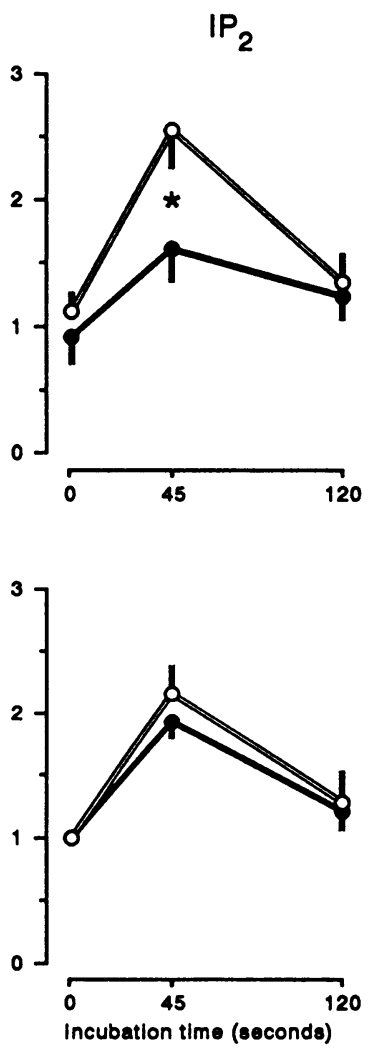
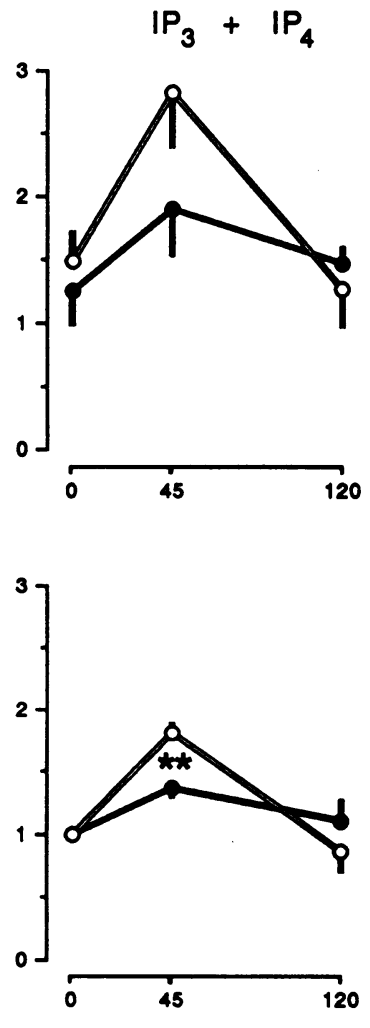

Figure 2. Time course of stimulation by $10^{-7}-\mathrm{M}$ arginine vasopressin of individual water-soluble $\left[{ }^{3} \mathrm{H}\right]$ inositol phosphates in aortic segments from virgin $(n=7)$ and pregnant $(n=8)$ rats. See Methods for details. $I P_{1}$, inositol monophosphate; $I P_{2}$, inositol bisphosphate; and $I P_{3}+I P_{4}$, inositol tris- plus tetrakisphosphate. ${ }^{*} P<0.05,{ }^{* *} P$ $<0.005$ virgin vs. pregnant at the same time point by unpaired $t$ tests. 

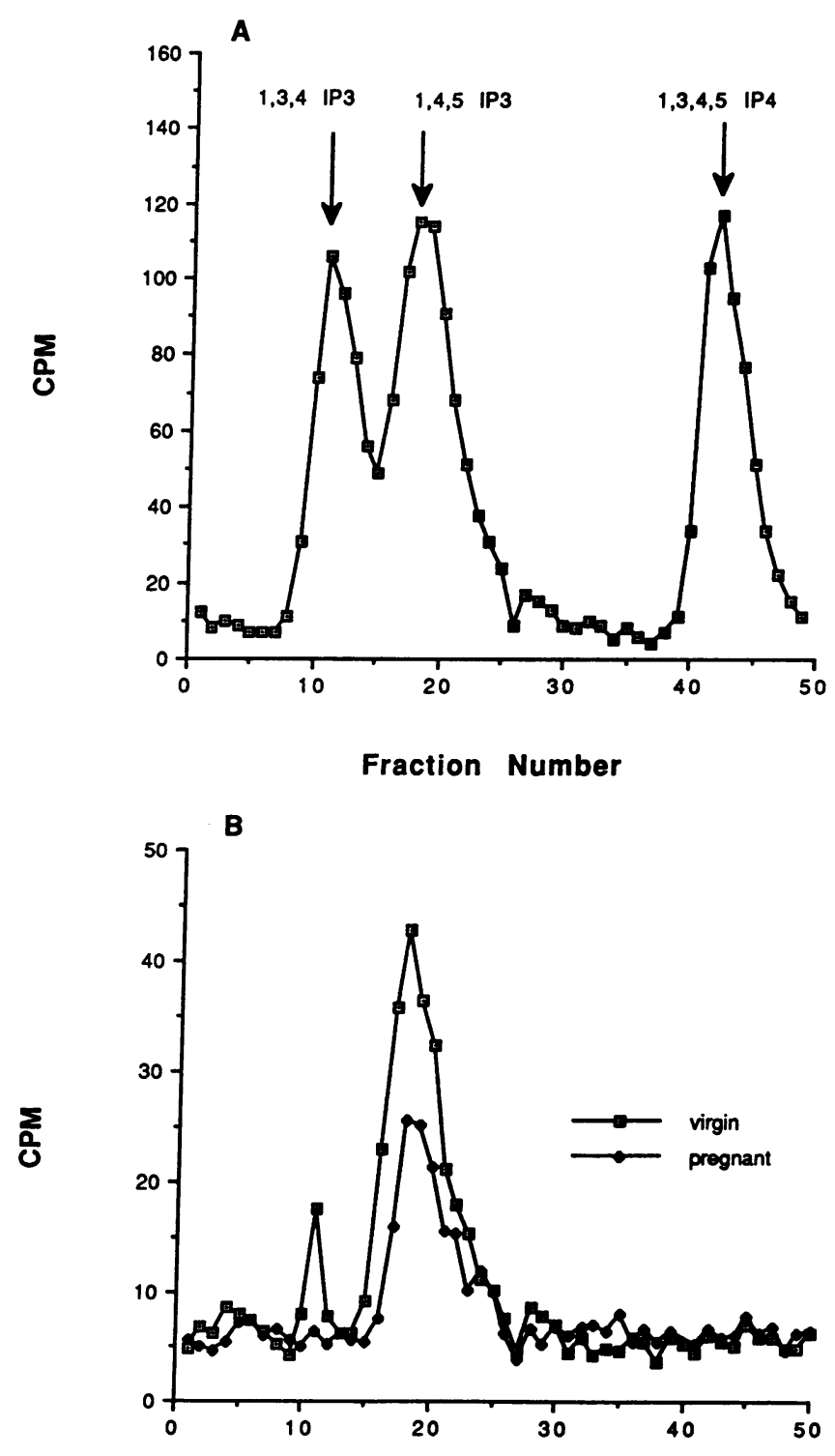

Fraction Number

Figure 3. Representative HPLC analyses of $\left[{ }^{3} \mathrm{H}\right]$ inositol phosphates synthesized by aortic segments in response to $10^{-7} \mathrm{M}$ arginine vasopressin for $30 \mathrm{~s}$. (A) A typical HPLC profile of a mixture of $\left[{ }^{3} \mathrm{H}\right]-$ inositol phosphate standards applied to the column. (B) A representative experiment in which the $\mathrm{IP}_{3}+\mathrm{IP}_{4}$ fractions from the Sep-Pak anion exchange columns were applied to the HPLC. See Methods for details.

maternal vasodilation. Most (14-20), but not all (41) investigators have demonstrated that the vasculature of gravid rats exhibits attenuated reactivity to vasoconstrictors in vitro or in situ. Conduit vessels including the aorta $(14,16,19,22)$, as well as resistance vessels $(17,20)$ develop attenuated reactivity during gestation. Further, the affinity and density of receptors responsible for mediating the response to vasoconstrictors during pregnancy have generally been reported not to be altered (23$26,42)$. Vasodilatory prostaglandins may not underlie these changes in vascular response to vasoconstrictor administration $(11,22)$. These studies were designed to evaluate the hypothesis that alterations in postreceptor mechanisms that mediate vaso-
Table III. HPLC Profile of ${ }^{3}$ H]Inositol Phosphate Synthesized by Freshly Isolated Aortic Segments in Response to $10^{-7} M$ Arginine Vasopressin

\begin{tabular}{|c|c|c|c|c|}
\hline \multirow{2}{*}{$\begin{array}{l}\text { Condition of } \\
\text { Rats }\end{array}$} & \multicolumn{4}{|c|}{$\left[{ }^{3} \mathrm{H}\right]$ Inositol phosphate } \\
\hline & Time(s) & $(1,3,4) I P_{3}$ & $(1,4,5) I P_{3}$ & $(1,3,4,5) I P$ \\
\hline & \multicolumn{4}{|c|}{$\mathrm{cpm} / \mathrm{mg}$ aortic protein } \\
\hline Pregnant & 30 & 4 & 176 & 4 \\
\hline Virgin & 30 & 15 & 247 & 8 \\
\hline Pregnant & 30 & 0 & 114 & 0 \\
\hline Virgin & 30 & 37 & 242 & 0 \\
\hline Pregnant & 60 & 0 & 105 & - \\
\hline Virgin & 60 & 0 & 116 & 0 \\
\hline
\end{tabular}

* These data were gathered from three different virgin and pregnant rats. Aortic segments were labeled with $10 \mu \mathrm{Ci} / \mathrm{ml}\left[{ }^{3} \mathrm{H}\right]$ myo-inositol for $3 \mathrm{~h}$, incubated with $10^{-7} \mathrm{M}$ AVP for 30 or 60 s, extracted with perchloric acid, and the water-soluble inositol phosphates then separated by Sep-Pak chromatography. The inositol trisphosphate plus tetrakisphosphate fraction was further separated by HPLC. See Methods for details.

constriction, specifically of inositol lipid metabolism may account for vasodilation and reduced vascular reactivity that $o c-$ cur during pregnancy.

We first examined the production of total $\left[{ }^{3} \mathrm{H}\right]$ inositol phosphates in the presence of $10 \mathrm{mM} \mathrm{LiCl}$ as an index of phosphoinositide hydrolysis. Because basal production was altered in vessels from gravid animals (see below), hormone-stimulated data were factored by basal values ("fold stimulation"). The fold stimulation by maximal doses of angiotensin II, arginine vasopressin, and norepinephrine was not significantly different between aortae from gravid and virgin rats (Table II). Moreover, the dose-response curves for arginine vasopressin obtained in vessels from both groups of animals were similar (see Results). These data suggest that activation of phospholipase $\mathrm{C}$ by vasoconstrictors is similar in aortae from pregnant and virgin rats. However, insofar as these experiments were conducted over a 15-min time period in the presence of $\mathrm{LiCl}$, inositol monophosphate was probably the most abundant inositol phosphate measured. Comparatively smaller changes in Ins $\mathrm{P}_{1,4,5}$ produced at early time periods after addition of agonist were therefore overlooked. Because Ins $P_{1,4,5}$ contributes to the initial rise in intracellular calcium critical for development of smooth muscle contraction, we next measured this product within seconds to minutes following agonist stimulation. $45 \mathrm{~s}$ after application of arginine vasopressin $\left(10^{-7} \mathrm{M}\right.$ final concentration), the fold stimulation of $\left[{ }^{3} \mathrm{H}\right]$ inositol tris- plus tetrakisphosphate was significantly less in vessels from gravid rats $(P$ $<0.005$ vs. virgin; Fig. 2 B). Further separation of $\left[{ }^{3} \mathrm{H}\right]$ inositol tris- plus tetrakisphosphate by HPLC indicated that greater than $90 \%$ of the total radioactivity was in the form of $\operatorname{InsP}_{1,4,5}$ (Fig. 3 and Table III). With the caveat that a reduction of radioactive Ins $\mathrm{P}_{1,4,5}$ does not necessarily imply a reduction in mass, the data suggest important biochemical differences are present in aortic tissue of virgin and pregnant rats.

Basal accumulation of $\left[{ }^{3} \mathrm{H}\right]$ inositol phosphates was reduced in aortae of gravid rats (Fig. 1 and Table I). This finding could result from reduced labeling of phosphoinositides with $\left[{ }^{3} \mathrm{H}\right]-$ myo-inositol (Fig. 4, $A-D$ ). Indeed, decreased labeling of the 
A

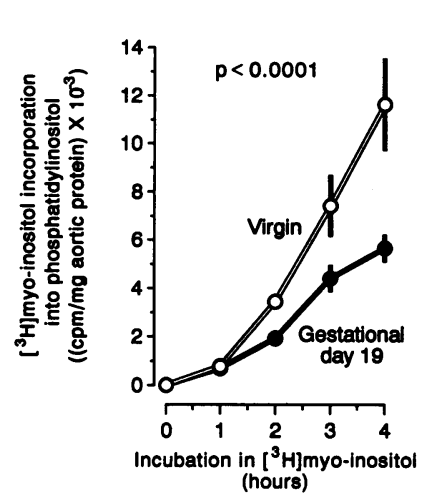

C
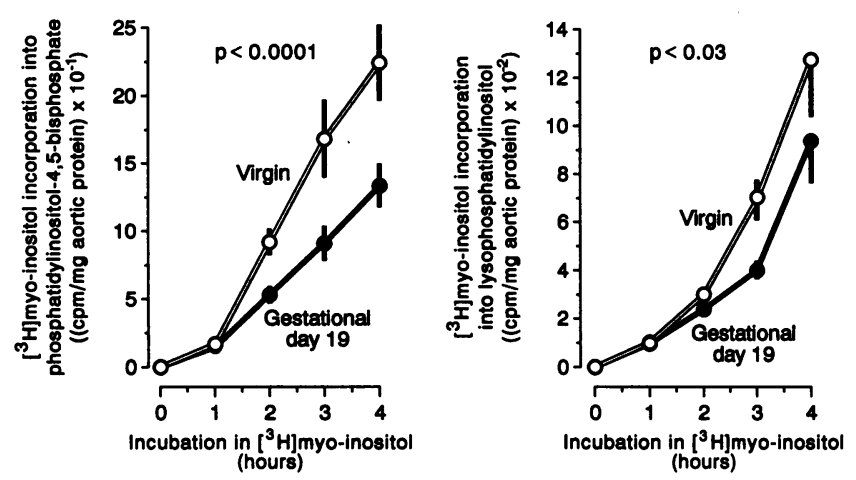

Figure 4. Time course of basal $\left[{ }^{3} \mathrm{H}\right]$ myo-inositol incorporation into phosphoinositides of aortic segments obtained from virgin and gravid rats ( $n=9$ animals in each group). The tissues were loaded for $1,2,3$, or $4 \mathrm{~h}$ with $\left[{ }^{3} \mathrm{H}\right]$ myo-inositol $(6 \mu \mathrm{Ci} / \mathrm{ml})$. Only labeled myo-inositol was added to the medium, so that the final concentration was 0.49 $\mu \mathrm{M}$. See Methods for details. Statistics were performed by two-factor ANOVA; the $P$ values given in the figures indicate that incorporation of $\left[{ }^{3} \mathrm{H}\right]$ myo-inositol was significantly less in tissues from gravid rats when compared with that of virgin controls.

phospholipids was uniformly observed, whether the medium in which tissues were incubated contained $0.49 \mu \mathrm{M}$ myo-inositol or a more physiologic concentration of $50 \mu \mathrm{M}$, and whether the medium used was a simple balanced salt solution or a cellculture mixture (Table IV). When in vivo labeling experiments were performed in chronically instrumented conscious rats, significant reductions in incorporation of $\left[{ }^{3} \mathrm{H}\right]$ myo-inositol into phosphoinositides were again found in vessels from gravid animals (Fig. 6).

Possible explanations for diminished labeling of aortic phosphoinositides in gravid rats include: $(a)$ attenuated cellular uptake of $\left[{ }^{3} \mathrm{H}\right]$ myo-inositol, and $(b)$ decreased turnover of phosphoinositides. Decreased mass of phosphoinositides could also contribute to reduced $\left[{ }^{3} \mathrm{H}\right]$ myo-inositol incorporation. Before it can be incorporated into phosphoinositides, $\left[{ }^{3} \mathrm{H}\right]$ myoinositol must first be transported into cells. Our results suggest that the mechanism of uptake in freshly isolated rat aorta is a $\mathrm{Na}^{+}$-cotransport process, insofar as $\left[{ }^{3} \mathrm{H}\right]$ myo-inositol uptake was completely inhibited in a $\mathrm{K}^{+}$-free medium or by $1 \mathrm{mM}$ ouabain (see Results and Fig. 7 B). A Na ${ }^{+}$-cotransport mechanism for myo-inositol uptake has been reported for other tissues (reviewed in reference 43). We further observed that the rate of uptake of $\left[{ }^{3} \mathrm{H}\right]$ myo-inositol into vessels from gravid rats was $24 \%$ less than uptake by vessels from virgin animals (Fig. 7 $A$ ). Although reduced cellular uptake of $\left[{ }^{3} \mathrm{H}\right]$ myo-inositol undoubtedly contributed to deficient labeling of phosphoinositides, this explanation alone cannot account for the diminished labeling because the rate of incorporation of $\left[{ }^{3} \mathrm{H}\right]$ myo-inositol into phosphoinositides was reduced by a greater extent, approximately $50 \%$ (Fig. 4 and Table IV).

These results are compatible with the view that the turnover of phosphoinositides is attenuated in aortae of gravid rats. The fact that, in addition to reduced incorporation of $\left[{ }^{3} \mathrm{H}\right]$ myoinositol, the uptake of $\left[{ }^{3} \mathrm{H}\right]$ glycerol into phosphatidylinositol (Fig. $5 \mathrm{~A}$; but not into phosphatidylserine, Fig. $5 \mathrm{~B}$ ) was also compromised, further supports the idea that phosphoinositide turnover is attenuated in vessels from gravid rats. Comparatively less incorporation of $\left[{ }^{3} \mathrm{H}\right]$ glycerol persisted even when uptake into phosphatidylinositol was stimulated by norepinephrine (Fig. $5 \mathrm{~A}$ ).

In aortic vasculature from gravid rats, it is possible that reduced cellular uptake of myo-inositol limits the availability of intracellular myo-inositol for optimal synthesis of phosphatidylinositol. Consequently, basal as well as hormone-stimu-

Table IV. [ ${ }^{3}$ H]Myo-inositol Incorporation into Phosphoinositides of Aortic Tissue*

\begin{tabular}{|c|c|c|c|c|c|c|c|}
\hline & & \multicolumn{4}{|c|}{ Hours in $\left[{ }^{3} \mathrm{H}\right]$ myo-inositol } & \multicolumn{2}{|c|}{ ANOVA } \\
\hline & & \multicolumn{4}{|c|}{$\mathrm{cpm} / \mathrm{mg}$ aortic wet weight } & \multirow[b]{2}{*}{ Virgin vs. pregnant } & \multirow[b]{2}{*}{ Time } \\
\hline & & 1.0 & 2.0 & 3.0 & 4.0 & & \\
\hline & rats $(n)$ & & & & & & \\
\hline \multirow{2}{*}{ Phosphatidylinositol } & Virgin (7) & $51.6 \pm 14.0$ & $147.7 \pm 27.2$ & $203.7 \pm 23.2$ & $303.6 \pm 59.1$ & $P<0.005$ & $P<0.001$ \\
\hline & Pregnant (7) & $45.8 \pm 13.3$ & $96.2 \pm 12.7$ & $135.1 \pm 14.8$ & $177.9 \pm 25.0$ & & \\
\hline \multirow[t]{2}{*}{ Lysophosphatidylinositol } & Virgin (7) & $7.8 \pm 1.2$ & $15.7 \pm 2.3$ & $20.6 \pm 2.4$ & $34.3 \pm 5.7$ & $P<0.001$ & $P<0.001$ \\
\hline & Pregnant (7) & $6.1 \pm 1.6$ & $8.7 \pm 1.7$ & $13.1 \pm 1.6$ & $21.7 \pm 2.6$ & & \\
\hline \multirow{2}{*}{$\begin{array}{l}\text { Phosphatidylinositol-4- } \\
\text { phosphate }\end{array}$} & Virgin (7) & $1.7 \pm 0.4$ & $5.3 \pm 0.8$ & $8.6 \pm 1.5$ & $9.8 \pm 1.9$ & $P<0.01$ & $P<0.001$ \\
\hline & Pregnant (7) & $1.3 \pm 0.2$ & $4.3 \pm 0.3$ & $5.9 \pm 0.9$ & $6.0 \pm 0.9$ & & \\
\hline \multirow{2}{*}{$\begin{array}{l}\text { Phosphatidylinositol-4,5- } \\
\text { bisphosphate }\end{array}$} & Virgin (7) & $3.7 \pm 0.8$ & $12.1 \pm 2.5$ & $17.1 \pm 3.8$ & $28.0 \pm 5.0$ & $P=0.13$ & $P<0.001$ \\
\hline & Pregnant (7) & $3.6 \pm 0.8$ & $7.7 \pm 1.3$ & $13.1 \pm 2.6$ & $23.3 \pm 4.7$ & & \\
\hline
\end{tabular}

* Mean \pm SEM. Incubation media were Earle's Balanced Salt Solution ( $n=4$ rats) or Ham's F12: Eagles Minimal Essential Medium 1:1 ( $n=3$ rats) containing 50 and $55 \mu \mathrm{M}$ myo-inositol, respectively. The results were similar and, therefore, combined. Pregnant rats were at day 20 of gestation. 

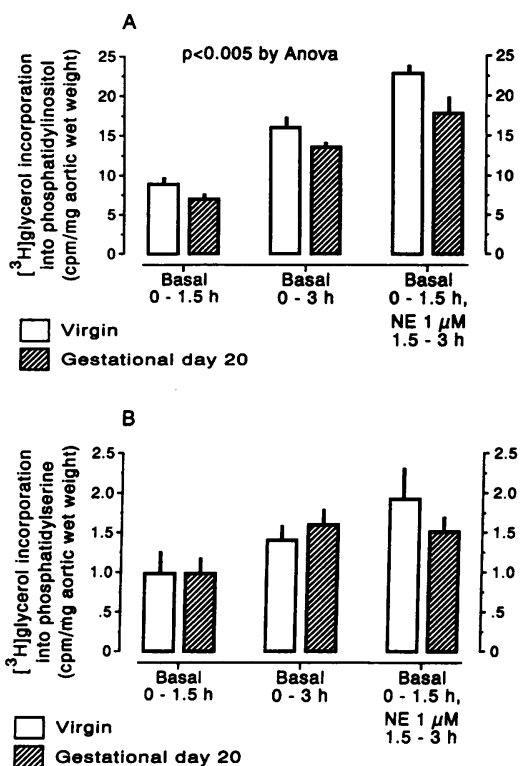

Figure 5. $\left[{ }^{3} \mathrm{H}\right]$ glycerol incorporation into phosphatidylinositol and phosphatidylserine of aortic segments obtained from virgin and gravid rats $(n=9$ rats in each group). Three aortic segments were used from each animal. One of the segments was incubated with 6 $\mu \mathrm{Ci} / \mathrm{ml}\left[{ }^{3} \mathrm{H}\right]$ glycerol for $1.5 \mathrm{~h}$, a second segment for $3.0 \mathrm{~h}$, and a third also for $3.0 \mathrm{~h}$. The third segment, however, was exposed to $1 \mu \mathrm{M}$ norepinephrine $(N E)$ during the last $1.5 \mathrm{~h}$ of incubation. Medium concentrations of myo-inositol and glyc-

erol were 50 and $100 \mu \mathrm{M}$, respectively. After loading of the aortic tissues, they were thoroughly washed, and phospholipids were extracted and separated by thin layer chromatography as described in Methods. Statistics were performed by two-factor ANOVA; the $P$ value given in the figure indicates that overall, incorporation of $\left[{ }^{3} \mathrm{H}\right]$ glycerol into phosphatidylinositol was significantly less in aortae from gravid rats when compared with that in vessels from virgin controls.

lated turnover of phosphoinositides could be compromised. Indeed, measurement of aortic myo-inositol content by GC/ MS demonstrated that vessels from pregnant rats contained $22 \pm 6 \%$ less myo-inositol (see Results). Because the $K_{\mathrm{m}}$ for myo-inositol CDP-diacylglycerol: inositol phosphatidyltrans-

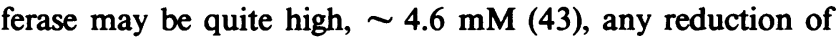
intracellular myo-inositol could compromise synthesis of phosphatidylinositol and, thus, of polyphosphoinositides. Interestingly, the concept that reduced availability of myo-inositol could compromise phosphatidylinositol biosynthesis has been invoked to explain the change in phospholipid content of surfactant during lung maturation $(44,45)$, the neuropathy of diabetes (46), the salutory effect of $\mathrm{Li}^{+}$in affective disorders $(47$, 48 ), as well as the accumulation of triacylglycerol in liver and intestinal lipodystrophy which occur with deficiency of dietary inositol (reviewed in reference 43).

The mechanism of reduced myo-inositol uptake by aortic vasculature of gravid rats is unknown. We considered the possibility that elevated plasma levels could downregulate the transporter. However, two independent methods of measurement failed to reveal significant differences in plasma myo-inositol concentrations between virgin and pregnant rats (see Results). In addition to alterations of the $K_{\mathrm{m}}$ or $V_{\max }$ of the $\mathrm{Na} / \mathrm{myo}$-inositol cotransporter, differences in $\mathrm{Na} / \mathrm{K}$ ATPase activity could be responsible. Indeed, increased levels of circulating digitalislike natriuretic factor have been reported in pregnancy (49). It would be of interest to determine if the defect in myo-inositol uptake that we observed is specific to vasculature, and whether other substances that undergo $\mathrm{Na}^{+}$-cotransport are also affected.

In summary, we have acquired evidence for attenuation of myo-inositol uptake, phosphoinositide turnover, and inositol
A

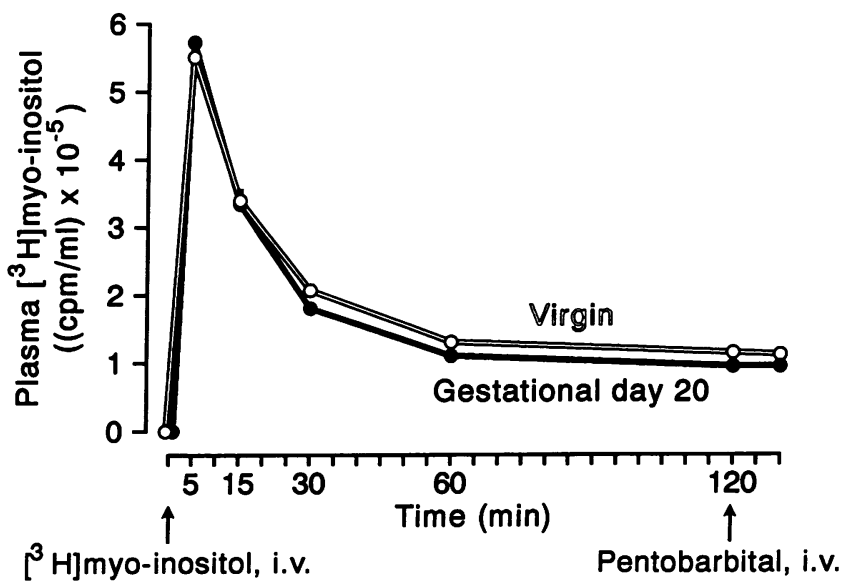

B

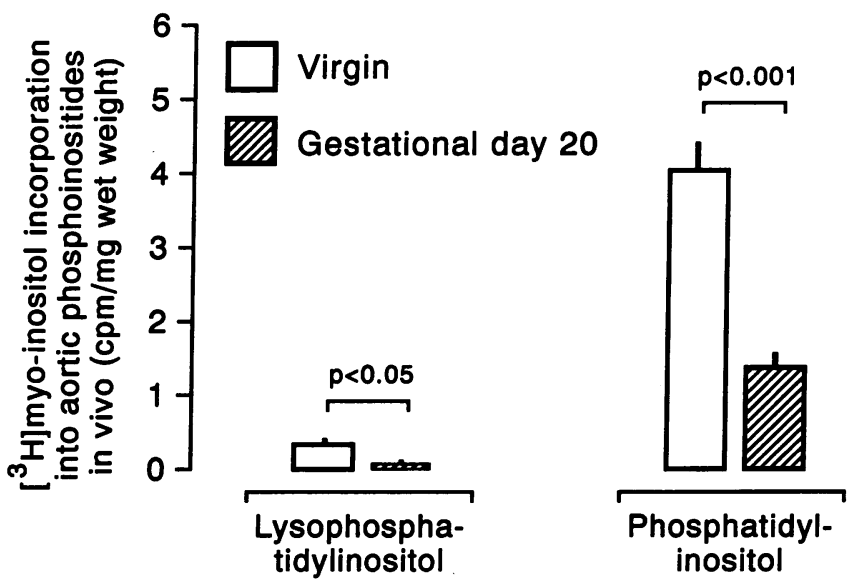

Figure 6. $\left[{ }^{3} \mathrm{H}\right]$ myo-inositol incorporation into phosphoinositides of aortic segments in vivo. Four chronically instrumented virgin and pregnant rats were administered $\left[{ }^{3} \mathrm{H}\right]$ myo-inositol intravenously $(50$ $\mu \mathrm{Ci} / 275 \mathrm{~g}$ and $43 \mu \mathrm{Ci} / 275 \mathrm{~g}$ body weight, respectively). Two-factor ANOVA revealed no significant difference in plasma radioactivity between virgin and gravid animals $(A) .2 \mathrm{~h}$ after administration of $\left[{ }^{3} \mathrm{H}\right]$ myo-inositol, the animals were killed, the aortae removed, and analyzed for labeling of phosphoinositides (see Methods). $(B)\left[{ }^{3} \mathrm{H}\right]$ myoinositol labeling of lysophosphatidylinositol and phosphatidylinositol. Significantly less incorporation of the label was observed in aortic phosphoinositides of pregnant animals (unpaired $t$ tests).

phosphate production in aortic vasculature of rats during pregnancy. If these alterations also occur in resistance vessels, they could contribute to vasodilation and/or attenuated pressor responsiveness of pregnancy. A unifying theory is that reduced myo-inositol uptake is limiting intracellular availability of myo-inositol for optimal synthesis of phosphatidylinositol and, consequently, of polyphosphoinositides. On this basis, both basal and hormone-stimulated turnover of phosphoinositides and production of inositol phosphates could be compromised. On the other hand, multiple defects may be operative, e.g., alteration of G-protein function, activity of phospholipase C, or of other enzymes in the signal transduction pathway. Clearly, further investigation is needed to clarify this issue, as well as to identify the factor(s) responsible for initiating the 


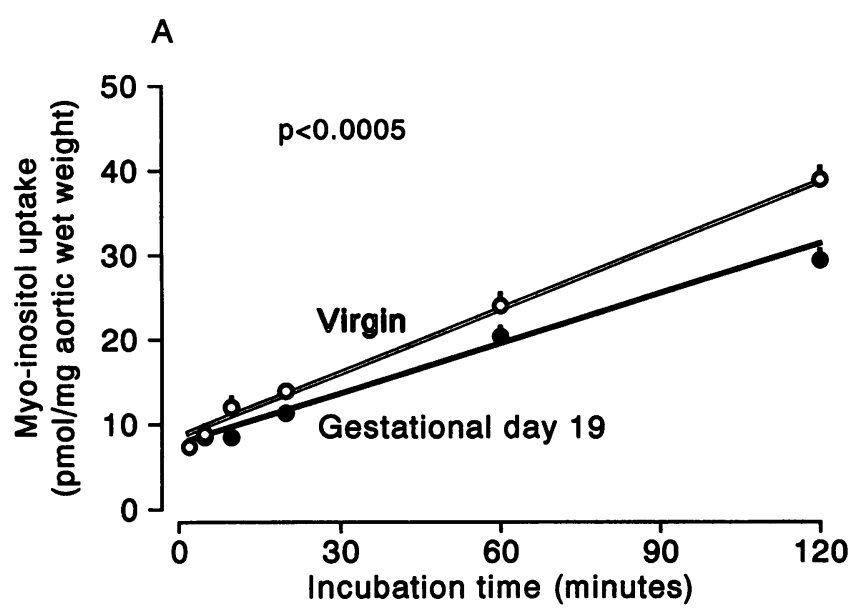

B

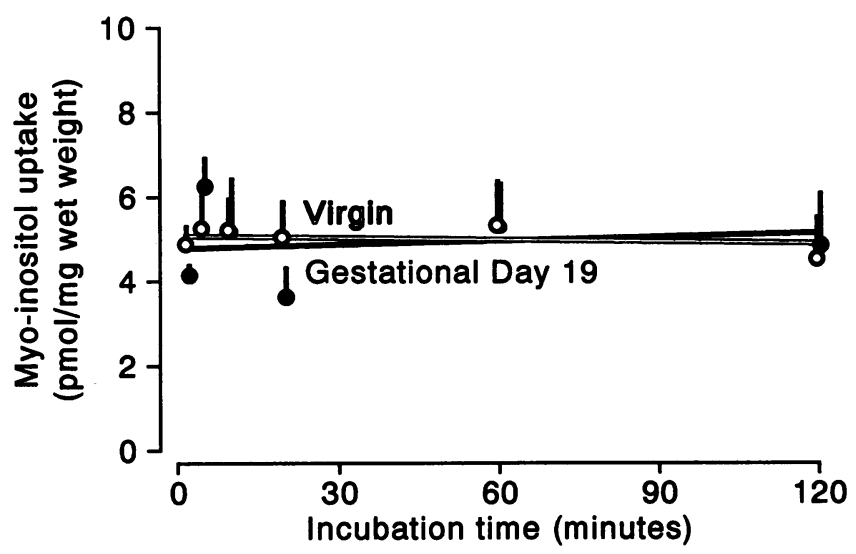

Figure 7. $\left[{ }^{3} \mathrm{H}\right]$ myo-inositol uptake into aortic segments of virgin and pregnant rats $(n=8$ animals each). Tissues were preincubated for 1 $\mathrm{h}$ in the presence $(A)$ or absence $(B)$ of $\mathrm{K}^{+}$. The final concentration of myo-inositol was $50 \mu \mathrm{M}$. See Methods for details. Two-factor ANOVA was performed in $A$; the $P$ value given in the figure indicates that overall, uptake of $\left[{ }^{3} \mathrm{H}\right]$ myo-inositol was significantly less in aortic segments obtained from gravid rats, when compared with that of virgin controls. The slopes of the lines were $0.27 \pm 0.03$ and $0.19 \pm 0.01$ for virgin and pregnant animals, respectively $(P=0.02)$. In the absence of $\mathrm{K}^{+}(B)$, little or no uptake was detected in aortae from either virgin or pregnant animals.

biochemical alterations observed in vasculature of pregnant rats.

\section{Acknowledgments}

The authors thank Dr. Thomas Knauss for an introduction to the technique of Dowex anion exchange chromatography of inositol phosphates as well as George Dubyak and Heinz Valtin for helpful discussions. The technical support of JoAnn N. Purdy in the GC/MS Facility at Dartmouth College and the clerical assistance of Valerie Jaramillo and Angela Jaramillo are also gratefully acknowledged.

This work was supported by National Institutes of Health grants HD-00662, and HL-38076 (to Dr. Conrad), and GM-34399 (to Dr. Friedman). Dr. Conrad is the recipient of the 8th Mallinckrodt Scholar Award.

\section{References}

1. Ueland, K., M. J. Novy, E. N. Peterson, and J. Metcalfe. 1969. Maternal cardiovascular dynamics. IV. The influence of gestational age on the maternal cardiovascular response to posture and exercise. Am. J. Obstet. Gynecol. 104:856-864.

2. Robson, S. C., S. Hunter, R. J. Boys, and W. Dunlop. 1989. Serial study of factors influencing changes in cardiac output during human pregnancy. Am. J. Physiol. 256:H1060-H1065.

3. Davison, J. M. 1987. Overview: kidney function in pregnant women. Am. J. Kidney Dis. 9:248-252.

4. MacGillivray, I., G. A. Rose, and B. Rowe. 1969. Blood pressure survey in pregnancy. Clin. Sci. 37:395-407.

5. Reiss, R. E., R. W. O’Shaughnessy, T. J. Quilligan, and F. P. Zuspan. 1987. Retrospective comparison of blood pressure course during preeclamptic and matched control pregnancies. Am. J. Obstet. Gynecol. 156:894-898.

6. Gant, N. F., G. L. Daley, S. Chand, P. J. Whalley, and P. C. MacDonald. 1973. A study of angiotensin II pressor response throughout primigravid pregnancy. J. Clin. Invest. 52:2682-2689.

7. Nisell, H., P. Hjemdahl, and B. Linde. 1985. Cardiovascular responses to circulating catecholamines in normal pregnancy and in pregnancy-induced hypertension. Clin. Physiol. 5:479-493.

8. Groenendijk, R., J. B. M. J. Trimbos, and H. C. S. Wallenburg. 1984 Hemodynamic measurements in preeclampsia: preliminary observations. Am. $J$. Obstet. Gynecol. 150:232-236.

9. Chesley, L. C., and G. M. Duffus. 1971. Preeclampsia, posture and renal function. Obstet. Gynecol. 38:1-5.

10. Conrad, K. P. 1984. Renal hemodynamics during pregnancy in chronically catheterized, conscious rats. Kidney Int. 26:24-29.

11. Conrad, K. P., and M. C. Colpoys. 1986. Evidence against the hypothesis that prostaglandins are the vasodepressor agents of pregnancy: serial studies in chronically instrumented, conscious rats. J. Clin. Invest. 77:236-245.

12. Conrad, K. P. 1987. Possible mechanisms for changes in renal hemodynamics during pregnancy: studies from animal models. Am. J. Kidney Dis. 9:253-259.

13. Conrad, K. P., P. M. Morganelli, T. Brinck-Johnsen, and M. C. Colpoys. 1989. The renin-angiotensin system during pregnancy in chronically instrumented, conscious rats. Am. J. Obstet. Gynecol. 161:1065-1072.

14. Dogterom, J., and W. DE Jong. 1974. Diminished pressor response to noradrenaline of the perfused tail artery of pregnant rats. Eur. J. Pharmacol. 25:267-269.

15. Fuchs, K. I., L. G. Moore, and S. Rounds. 1982. Pulmonary vascular reactivity is blunted in pregnant rats. J. Appl. Physiol. 53:703-707.

16. Hart, J. L. 1982. Barium responsiveness of the rat aorta and femoral artery during pregnancy. Life Sci. 30:163-169.

17. McLaughlin, M. K., and T. M. Keve. 1986. Pregnancy-induced changes in resistance blood vessels. Am. J. Obstet. Gynecol. 155:1296-1299.

18. Massicotte, G., J. St-Louis, A. Parent, and E. L. Schiffrin. 1987. Decreased in vitro responses to vasoconstrictors during gestation in normotensive and spontaneously hypertensive rats. Can. J. Physiol. Pharmacol. 65:2466-2471.

19. St.-Louis, J., A. Parent, J. Gutkowska, J. Genest, and E. L. Schiffrin. 1988. Vasorelaxation and vascular binding sites for atrial natriuretic peptide in pregnant rats. Am. J. Physiol. 254:H1027-H1033.

20. Crandall, M. E., T. M. Keve, and M. K. McLaughlin. 1990. Characterization of norepinephrine sensitivity in the rat mesenteric circulation during pregnancy. Am. J. Obstet. Gynecol. 162:1296-1301.

21. Hardebo, J. E., and L. Edvinsson. 1977. Reduced sensitivity to alpha- and beta-adrenergic receptor agonists of intra- and extracranial vessels during pregnancy. Relevance to migraine. Acta. Neurol. Scand. 64:204-205.

22. Harrison, G. L., and L. G. Moore. 1989. Blunted vasoreactivity in pregnant guinea pigs is not restored by meclofenamate. Am. J. Obstet. Gynecol. 160:258-264.

23. Brown, G. P., and R. C. Venuto. 1988. Angiotensin II receptors in rabbit renal preglomerular vessels. Am. J. Physiol. 255:E16-E22.

24. Paller, M. S. 1984. Mechanism of decreased pressor responsiveness to ANG II, NE and vasopressin in pregnant rats. Am. J. Physiol. 247:H100-H108.

25. Parent, A. J. St-Louis, and E. L. Schiffrin. 1988. Binding sites for AVP, ANG II and ANP in the mesenteric artery during pregnancy in the rat. Intern. Soc. Study Hypertension Pregnancy. 6th International Congress. 283a. (Abstr.)

26. Mackanjee, H. R., P. W. Shaul, R. R. Magness, and C. R. Rosenfeld. 1989. Angiotensin II receptors in systemic and uterine vascular smooth muscle in ovine pregnancy. Soc. Gynecol. Invest. 36:165a. (Abstr.)

27. Conrad, K. P., and M. J. Dunn. 1987. Renal synthesis and urinary excretion of eicosanoids during pregnancy in rats. Am. J. Physiol. 253:F1197-F1205.

28. Conrad, K. P., and K. A. Vernier. 1989. Plasma level, urinary excretion, and metabolic production of CGMP during gestation in rats. Am. J. Physiol. 257:R847-R853.

29. Umans, J. G., M. D. Lindheimer, and W. M. Barron. 1990. Pressor effect of endothelium-derived relaxing factor inhibition in conscious virgin and gravid rats. Am. J. Physiol. 259:F293-F296.

30. Rasmussen, H., Y. Takuma, and S. Park. 1987. Protein kinase $C$ in the regulation of smooth muscle contraction. FASEB (Fed. Am. Soc. Exp. Biol.) J. 1:177-185. 
31. Griendling, K. K., S. E. Rittenhouse, T. A. Brock, L. S. Ekstein, M. A. Gimbrone, Jr., and R. W. Alexander. 1986. Sustained diacylglycerol formation from inositol phospholipids in angiotensin II-stimulated vascular smooth muscle cells. J. Biol. Chem. 261:5901-5906.

32. Berridge, M. J., R. M. C. Dawson, C. P. Downes, J. P. Heslop, and R. F. Irvine. 1983. Changes in the levels of inositol phosphates after agonist-dependent hydrolysis of membrane phosphoinositides. Biochem. J. 212:473-482.

33. Wreggett, K. A., and R. F. Irvine. 1987. A rapid separation method for inositol phosphates and their isomers. Biochem. J. 245:655-660.

34. Gonzalez-Sastre, F., and J. Folch-Pi. 1968. Thin-layer chromatography of the phosphoinositides. J. Lipid. Res. 9:532-533.

35. Mahadevappa, V. G., and B. J. Holub. 1987. Chromatographic analysis of phosphoinositides and their breakdown products in activated blood platelets/ neutrophils. In Journal of Chromatography Library. A. Kuksis, editor. Elsevier, Amsterdam. 37:225-265.

36. Weissbach, A. 1958. The enzymatic determination of myo-inositol. Biochem. Biophys. Acta. 27:608-611.

37. MacGregor, L. C., and F. M. Matschinsky. 1984. An enzymatic fluorometric assay for myo-inositol. Anal. Biochem. 141:382-389.

38. Wells, W. W., T. Chin, and B. Weber. 1964. Quantitative analysis of serum and urine sugars by gas chromatography. Clin. Chim. Acta. 10:352-359.

39. Wells, W. W., T. A. Pittman, and H. J. Wells. 1965. Quantitative analysis of myoinositol in rat tissue by gas-liquid chromatography. Anal. Biochem. 10:450-458.
40. Lowry, O. H., N. J. Rosebrough, A. L. Farr, and R. J. Randall. 1951. Protein measurement with Folin phenol reagent. J. Biol. Chem. 193:265-275.

41. Hart, J. L., W. Freas, and S. M. Muldoon. 1986. Neurovascular function in the rat during pregnancy. Am. J. Physiol. 251:H1000-H1008.

42. Brown, G. P., and R. C. Venuto. 1986. Angiotensin II receptor alterations during pregnancy in rabbits. Am. J. Physiol. 251:E58-E64.

43. Holub, B. J. 1986. Metabolism and function of myo-inositol and inositol phospholipids. Annu. Rev. Nutr. 6:563-597.

44. Bleasdale, J. E., M. C. Maberry, and J. G. Quirk. 1982. Myo-inositol homeostasis in foetal rabbit lung. Biochem. J. 206:43-52.

45. Bleasdale, J. E., N. E. Tyler, F. N. Busch, and J. G. Quirk. 1983. The influence of myo-inositol on phosphatidylglycerol synthesis by rat type II pneumonocytes. Biochem. J. 212:811-818.

46. Winegrad, A. I. 1987. Does a common mechanism induce the diverse complications of diabetes? Diabetes. 36:396-406.

47. Berridge, M. J., C. P. Downes, and M. R. Hanley. 1982. Lithium amplifies agonist-dependent phosphatidylinositol responses in brain and salivary glands. Biochem. J. 206:587-595.

48. Kennedy, E. D., R. A. J. Challiss, C. I. Ragan, and S. R. Nahorski. 1990. Reduced inositol polyphosphate accumulation and inositol supply induced by lithium in stimulated cerebral cortex slices. Biochem. J. 267:781-786.

49. Graves, S. W., and G. H. Williams. 1987. Endogenous digitalis-like natriuretic factors. Annu. Rev. Med. 38:433-444. 